\title{
Does concomitance of Hashimoto's disease and type 1 diabetes affect diabetes control and development of its complications?
}

\author{
Grzegorz Szcześniak, Patrycja Kozak-Nurczyk, Piotr Dziemidok
}

Department of Diabetology, Institute of Rural Health, Lublin, Poland

Submitted: 18 February 2018; Accepted: 7 July 2018

Online publication: 16 November 2019

Arch Med Sci 2021; 17 (4): 900-904

DOI: https://doi.org/10.5114/aoms.2019.89780

Copyright @ 2019 Termedia \& Banach

\section{Abstract}

Introduction: Autoimmune diseases concomitant with diabetes may complicate the treatment and adversely affect the prognosis. The most common is Hashimoto's disease (HD). We compared diabetes control and prevalence of chronic complications in type 1 diabetes patients differing in the coexistence of HD.

Material and methods: Medical records of 188 type 1 diabetics were analysed. Hashimoto's disease was diagnosed based on medical history, as well as determination of the levels of thyroid peroxidase antibodies, hormones and ultrasound examination. Statistical analysis was performed using Statistica $10 \mathrm{PL}$.

Results: HD was diagnosed in $43(23 \%)$ patients. The mean $\mathrm{HbA}_{1 \mathrm{c}}$ was 8.8 $\pm 1.5 \%$ in the group with HD, and $9 \pm 1.6 \%$ in the group without HD (ns). The prevalence of diabetes complications was similar in both groups: ischaemic heart disease was diagnosed in $19 \%$ of patients with HD and $19 \%$ without HD, cerebral vascular insufficiency $-8 \%$ and $7 \%$, peripheral neuropathy - $14 \%$ and $12 \%$, sensory polyneuropathy $-47 \%$ and $46 \%$, diabetic foot $-7 \%$ and $8 \%$, Charcot osteoarthropathy $-7 \%$ and $2 \%$, cardiovascular neuropathy $-21 \%$ and $28 \%$, neuropathy of the gastrointestinal tract $-5 \%$ and $6 \%$, nephropathy $-12 \%$ and $19 \%$, retinopathy $-42 \%$ and $43 \%$, and cataract in $28 \%$ and $19 \%$, respectively. Impaired hypoglycaemia perception was rarer in the group with HD: $9 \%$ vs. $25 \%(p \approx 0.04)$.

Conclusions: Hashimoto's disease does not significantly affect the level of type 1 diabetes control or the development of its complications. Only autonomic neuropathy in the form of impaired awareness of hypoglycaemia is rarer in patients with that thyroiditis.

Key words: glycosylated haemoglobin, type 1 diabetes, Hashimoto thyroiditis, chronic diabetes complications.

\section{Introduction}

Type 1 diabetes is a disease which manifests due to absolute insulin deficiency, resulting from damage to more than $80 \%$ of pancreatic $\beta$ cells. This destruction occurs in genetically predisposed individuals as a result of the action of an environmental factor which triggers the autoimmune response directed towards pancreatic $\beta$ cells. To date, many types of antibodies leading to type 1 diabetes have been identified. The most important in clinical practice are insulin autoantibodies, against glutamic acid decarboxylase, against tyrosine phosphatase, and against zinc transporter [1].

\author{
Corresponding author: \\ Grzegorz Szcześniak \\ $\mathrm{MD}, \mathrm{PhD}$ \\ Department of Diabetology \\ Institute of Rural Health \\ 2 Kazimierza Jaczewskiego St \\ 20-090 Lublin, Poland \\ E-mail: \\ grzeszcze@poczta.wp.pl
}


Considering genetic predisposition, the genes of the major histocompatibility complex located on the short arm of chromosome 6 (6p21) show the strongest type 1 diabetes associations. Genes located in this region encode human leukocyte antigens. Many other autoimmune diseases show association with this region; therefore, they may co-occur with type 1 diabetes [1].

It is believed that other autoimmune diseases concomitant with type 1 diabetes complicate its treatment and adversely affect the prognosis. For example, Addison disease may cause unexpected hypoglycaemia [2, 3], celiac disease interferes with absorption of nutrients from food, and consequently causes difficulties in the adjustment of the dose of bolus insulin [4], and hyperthyroidism or hypothyroidism related to autoimmune thyroiditis increases insulin resistance [5].

The most prevalent autoimmune disease is Hashimoto's thyroiditis, which, at the same time, is the most frequently occurring type of thyroiditis and the most common cause of hypothyroidism. This disease is observed in all age groups, with an incidence of up to $2 \%$. Chronic thyroiditis of the Hashimoto type is also the most prevalent autoimmune disease concomitant with type 1 diabetes, and the most frequent endocrinopathy [6].

Many studies have confirmed more frequent concomitance of autoimmune diseases in diabetic patients and their relatives. For example, in the study by Goworek, Hashimoto's disease (HD) was diagnosed in $17.35 \%$ of patients with type 1 diabetes. According to the frequency of co-occurrence, the subsequent disorders were: albinism, celiac disease, rheumatoid arthritis and alopecia areata. In single cases, Sjögren syndrome, ulcerative colitis, and autoimmune hepatitis were also observed [7]. Kahaly and Hansen found that $15-30 \%$ of patients with type 1 diabetes suffer from autoimmune disease of the thyroid gland (HD or Graves' disease), 5-10\% - autoimmune gastritis and/or pernicious anaemia, 4-9\% celiac disease, 2-10\% - albinism, 0.5\% - Addison's disease. The above-mentioned researchers also reported that more than $1 / 3$ of these patients may develop autoimmune polyendocrine syndromes [8].

Also in patients with type 1 diabetes hospitalized in the Department of Diabetology at the Institute of Rural Health in Lublin the most frequent autoimmune disease concomitant with diabetes was Hashimoto's thyroiditis, diagnosed in $20 \%$ of patients. In $2 \%$ of the patients, Graves' disease was diagnosed, in 3\% albinism, in $2 \%$ AddisonBiermer anaemia and celiac disease, and in $1 \%$ rheumatoid arthritis. In single patients from this group, Sjögren syndrome, autoimmune vasculitis or stiff-man syndrome was diagnosed [9].

The objective of the study was to compare the degree of diabetes control and the frequency of complications in patients with type 1 diabetes, according to concomitance of HD.

\section{Material and methods}

Retrospective analysis was performed of randomly selected medical records of 188 patients with type 1 diabetes (94 females and 94 males) hospitalized in the Department of Diabetology at the Institute of Rural Health in Lublin during 2008-2016. Patients who had diabetes diagnosed for a period shorter than 2 years, and pregnant women, were not included in the study. Hashimoto's disease was diagnosed based on previous history taking, as well as an active search during hospitalization. The patients underwent a thorough physical examination, and all of them had the level of thyroid stimulating hormone (TSH) determined in blood plasma. In patients without earlier diagnosis, anti-thyroid peroxidase antibodies (anti-TPO), and more rarely also anti-thyroglobulin (anti-TG), were determined. In patients with elevated anti-TPO titres and/or an abnormal TSH level, the diagnostics was expanded by the determination of free hormones and thyroid ultrasound. All patients had anthropometric parameters determined (body mass, height, body mass index), glycosylated haemoglobin $\left(\mathrm{HbA}_{1 \mathrm{c}}\right)$ level, and were evaluated from the aspect of occurrence of chronic diabetes complication: analysis of previous medical records; exercise stress test, ECG Holter monitor test, echocardiography, and in single cases, heart scintigraphy in order to diagnose ischaemic heart disease; Doppler ultrasound of the carotid arteries when the symptoms of cerebral circulatory failure occurred, determination of ankle-brachial index, toe-brachial index, in selected cases Doppler ultrasound of lower extremity arteries to assess peripheral circulation disorders, the Neuropathy Total Syndrome Score (NTSS) questionnaire and the VAS scale, touch sensation using Semmes-Weinstein 5.07/10 gram monofilament, sensation of vibration using a $128 \mathrm{~Hz}$ RydelSeiffer tuning fork, or biothesiometer, examination of temperature sensitivity using Tip-Therm, pain sensation with sterile needle pinprick test using a sterile pin, evaluation of knee and ankle reflexes in order to assess the stage of sensory neuropathy; Ewing's test to evaluate the stage of cardiovascular neuropathy; upper gastrointestinal endoscopy for gastroparesis; assessment of microalbuminuria (measurement of urinary albumin excretion performed twice in a 24-hour collection, or ACR), level of creatinine in blood to diagnose nephropathy; and ophthalmological assessment.

\section{Statistical analysis}

Statistical analysis was performed using the software Statistica 10PL. Normal distribution of 
variables was examined by means of the Lilliefors test, which, in the majority of cases, showed a considerable deviation requiring the application of non-parametric tests (NW $\chi^{2}$ test, Mann-Whitney test, Kruskal-Wallis test).

\section{Results}

Hashimoto's disease was diagnosed in 43 patients in the study (23\%: $33 \%$ females and 13\% males; $p \approx 0.0001$ ); mean age $42.1 \pm 15$; duration of diabetes $16.8 \pm 10.3$, did not significantly differ between the examined groups. The method of treatment was also similar in both groups: in the group with Hashimoto's thyroiditis in the multiple daily injections system there were $38(84 \%)$ patients and personal insulin pump $7(16 \%)$ patients, while in the group without HD there were 132 (82\%) and 29 (18\%) patients, respectively (ns).

The mean $\mathrm{HbA}_{1 \mathrm{c}}$ level was $8.8 \pm 1.5 \%$ in the group with $\mathrm{HD}$, and $9.0 \pm 1.6 \%$ in patients without this disease (ns). The mean body mass index was estimated at $24.8 \pm 4.0$ and $25.8 \pm 4.7$ $\mathrm{kg} / \mathrm{m}^{2}$ (ns), respectively, whereas the prevalence of obesity was estimated at $14 \%$ and $18 \%$ (ns).

Among patients with HD prevailed euthyroidism, while $23 \%$ were diagnosed as hypothyroids. The prevalence of hypothyroidism in the group of patients with Hashimoto's thyroiditis was significantly higher, compared to the group of patients without this disease (Table I). The current function of the thyroid hormones has no effect on diabetes control and body weight (Table II).

Fourteen percent of patients with Hashimoto's thyroiditis and $10 \%$ without this disease were admitted due to ketoacidosis (ns). The prevalence of chronic complications of diabetes was similar in both groups; only impaired hypoglycaemia perception was diagnosed more rarely in the group with HD: $9 \%$ vs. $25 \%$ ( $p \approx 0.04)$ (Table III).

\section{Discussion}

In the relevant literature there are many data concerning the co-occurrence of diabetes and thyroid diseases and their mutual implications. However, there is little information about the effect of autoimmune thyroiditis on diabetes control and development of its chronic complications.

Thyroid hormones exert an effect on glycaemia through several mechanisms which are activated according to their level in various metabolic paths, which lead to an increase, and more rarely, to a decrease of glucose in blood. Hypothyroidism concerns an increased predisposition to hyperglycaemia by shortening the half-life of insulin as a result of increased degradation, and increased release of biologically inactive insulin precursors [10,11]. In addition, under the effect of thyroid hormones, there is increased hepatic glucose production due to an increase in the concentration of the glucose transporter GLUT2; its intestinal absorption also increases [11-14]. In turn, in hyperthyroidism, a limitation occurs in the availability of glucose in the body due to decreased hepatic glucose production. There is also a decrease in glucose-induced insulin secretion by the $\beta$-cells of the pancreatic islets, as well as intestinal glucose absorption. It is noteworthy that repeated episodes of hypoglycaemia are frequently the sign of developing hypothyroidism in patients with type 1 diabetes, and may be related to concomitant Addison's disease [15]. On the other hand, there is evidence confirming that both subclinical and evident hypothyroidism may be a risk factor of metabolic syndrome [16-18]. Maskey observed a higher level of cholesterol and triglycerides in the blood of diabetic patients with concomitant hypothyroidism. It has been proved that increased insulin resistance in hypothyroidism, especially subclinical, is associated with a re-

Table I. Functional state of the thyroid gland in the examined groups of patients (maximum likelihood ratio $\chi^{2}$ test)

\begin{tabular}{|lccccccc|}
\hline Functional state & \multicolumn{2}{c}{$\begin{array}{c}\text { Hashimoto's } \\
\text { thyroiditis }\end{array}$} & $\begin{array}{c}\text { Without Hashimoto's } \\
\text { thyroiditis }\end{array}$ & \multicolumn{2}{c}{ Total } & \multirow{2}{*}{-value } \\
\cline { 2 - 7 } & $n$ & $\%$ & $n$ & $\%$ & $n$ & $\%$ & \\
\hline Hypothyroidism & 10 & 23 & 2 & 1 & 12 & 6 \\
\hline Euthyroid & 32 & 74 & 131 & 91 & 163 & 87 & 0.000001 \\
\hline Subclinical hyperthyroidism & 1 & 2 & 11 & 8 & 12 & 6 \\
\hline
\end{tabular}

Table II. Effect of functional status of the thyroid gland on body mass index (BMI) and glycosylated haemoglobin $\mathrm{HbA}_{1 c}$ (Kruskal-Wallis test)

\begin{tabular}{|lccccc|}
\hline Parameter & Hypothyroidism & Euthyroid & $\begin{array}{l}\text { Subclinical hy- } \\
\text { perthyroidism }\end{array}$ & Total & $P$-value \\
\hline Mean BMI $\left[\mathrm{kg} / \mathrm{m}^{2}\right]$ & $26.3 \pm 4.5$ & $25.5 \pm 4.6$ & $24.9 \pm 4.5$ & $25.5 \pm 4.5$ & 0.7 \\
\hline Mean $\mathrm{HbA}_{1 \mathrm{c}}(\%)$ & $8.6 \pm 1.6$ & $9.0 \pm 1.6$ & $8.5 \pm 1.3$ & $9.0 \pm 1.6$ & 0.8 \\
\hline
\end{tabular}


Table III. Prevalence of chronic complications in the examined groups of patients (maximum likelihood ratio $\chi^{2}$ test)

\begin{tabular}{|c|c|c|c|c|c|c|c|}
\hline \multirow[t]{2}{*}{ Complication } & \multicolumn{2}{|c|}{$\begin{array}{l}\text { Hashimoto's } \\
\text { thyroiditis }\end{array}$} & \multicolumn{2}{|c|}{$\begin{array}{c}\text { Without Hashimoto's } \\
\text { thyroiditis }\end{array}$} & \multicolumn{2}{|c|}{ Total } & \multirow[t]{2}{*}{$P$-value } \\
\hline & $n$ & $\%$ & $n$ & $\%$ & $n$ & $\%$ & \\
\hline Ischaemic heart disease & 8 & 18 & 28 & 17 & 36 & 17 & 1 \\
\hline State after myocardial infarction & 0 & 0 & 7 & 4 & 7 & 3 & 0.1 \\
\hline Cerebral circulatory insufficiency & 3 & 7 & 12 & 7 & 15 & 7 & 0.8 \\
\hline State after cerebral stroke & 0 & 0 & 4 & 2 & 4 & 1 & 0.3 \\
\hline Peripheral vascular disease & 7 & 16 & 18 & 11 & 25 & 12 & 0.8 \\
\hline Peripheral sensory neuropathy & 21 & 47 & 67 & 42 & 88 & 43 & 0.9 \\
\hline Charcot osteoarthropathy & 3 & 7 & 3 & 2 & 6 & 3 & 0.1 \\
\hline Diabetic foot syndrome & 3 & 7 & 13 & 8 & 16 & 8 & 0.8 \\
\hline $\begin{array}{l}\text { State after lower extremity } \\
\text { amputation due to diabetic foot } \\
\text { syndrome }\end{array}$ & 2 & 4 & 5 & 3 & 7 & 3 & 0.7 \\
\hline Cardiovascular neuropathy & 9 & 20 & 40 & 25 & 49 & 24 & 0.4 \\
\hline Gastrointestinal neuropathy & 2 & 4 & 9 & 6 & 11 & 5 & 0.7 \\
\hline $\begin{array}{l}\text { Impaired hypoglycaemia } \\
\text { perception }\end{array}$ & 4 & 9 & 36 & 22 & 40 & 19 & 0.02 \\
\hline Diabetic neuropathy & 5 & 11 & 27 & 17 & 32 & 16 & 0.3 \\
\hline Diabetic retinopathy & 18 & 40 & 62 & 39 & 80 & 39 & 0.9 \\
\hline Cataract & 12 & 27 & 28 & 17 & 40 & 19 & 0.2 \\
\hline
\end{tabular}

duced response of the peripheral muscles [17].

Reports concerning the effect of thyroid function disorders on the occurrence of acute and chronic complications of diabetes are even more scarce. Nephropathy is more frequently observed in patients with type 2 diabetes and hypothyroidism $[19,20]$. Den Hollander et al. confirmed that treatment of hypothyroidism improves renal function in diabetic patients [21]. In $2011 \mathrm{Kim}$ et al. presented the results of their study in which a more severe form of retinopathy was noted in patients with type 2 diabetes with subclinical hypothyroidism, compared to euthyroid patients [22].

In the present study, no significant difference was found between the level of $\mathrm{HbA}_{1 c}$ in the group of patients with type 1 diabetes with concomitant $\mathrm{HD}$, and the level of $\mathrm{HbA}_{1 \mathrm{c}}$ in the group of patients with type 1 diabetes without autoimmune thyroid disease of this type. Nevertheless, in the light of the above-mentioned studies, considering the greater prevalence of hypothyroidism in the group of patients with HD, it should be expected that in this group glycaemia control would be worse. Moreover, the groups also did not differ with respect to body mass index, while hyperthyroidism favoured weight gain.

Considering metabolic disorders accompanying hyperthyroidism, it could be anticipated that in the group with $\mathrm{HD}$, the complications of diabetes, especially those which are macrovascular, would be more frequent. However, such a relationship was not observed in the present study. The rarer occurrence of autonomic neuropathy in the form of impaired hypoglycaemia perception in diabetic patients with chronic autoimmune thyroid disease is even more puzzling, because in the course of hyperthyroidism there occurs a reduction of symptoms related to the stimulation of the adrenergic system, while - as mentioned earlier - in patients with hypothyroidism, hypoglycaemia occurs more frequently [15], which makes it more likely that patients become accustomed to low levels of glucose in the blood.

Certainly the fact that the majority of patients with Hashimoto's thyroiditis were intensively treated with L-thyroxine had an effect on the results of the present study. Perhaps, in order to fully describe the effect of the concomitant presence of autoimmune thyroiditis on diabetes control and the development of chronic complications in patients with type 1 diabetes, it would be advisable to conduct studies in a larger population of patients, and perform a separate analysis in groups differing by functional status of the thyroid gland. Nevertheless, this study may form the nucleus for discussion of such a problem.

In conclusion, the concomitance of Hashimoto's thyroiditis does not significantly affect the degree of diabetes control and development of its 
complications. Only autonomic neuropathy in the form of impaired hyperglycaemia perception is more rarely observed in patients with this thyroid disease.

\section{Conflict of interest}

The authors declare no conflict of interest.

\section{References}

1. Dzida G. Etiopatogeneza cukrzycy typu 1. In: Sieradzki J (ed.). Cukrzyca. Chap. 1. $2^{\text {nd }}$ ed. Via Medica, Gdańsk 2015; 143-54.

2. Glynn N, Bashir M, Smith D, Thompson CJ. Newly diagnosed $\mathrm{T} 1$ diabetes presenting with hypoglycemia due to simultaneous co-existence of Addison disease. Pediatr Diabetes 2014; 15: 464-7.

3. Phornphutkul C, Boney CM, Gruppuso PA. A novel presentation of Addison disease: hypoglycemia unawareness in an adolescent with insulin-dependent diabetes mellitus. J Pediatr 1998; 132: 882-4.

4. Kurien M, Mollazadegan K, Sanders DS, Ludvigsson JF. A nationwide population-based study on the risk of coma, ketoacidosis and hypoglycemia in patients with celiac disease and type 1 diabetes. Acta Diabetol 2015; 52: 1167-74.

5. Iwen KA, Schröder E, Brabant G. Thyroid hormones and the metabolic syndrome. Eur Thyroid J 2013; 2: 83-92.

6. Jarząb B, Lewiński A, Płaczkiewicz-Jankowska E. Choroby tarczycy. In: Choroby Wewnętrzne. $1^{\text {st }}$ ed. Szczeklik A (ed.). Medycyna Praktyczna, Kraków 2005; 1033-82.

7. Goworek M, Madej A, Suwała S, Szadkowska A. Występowanie chorób autoimmunologicznych u osób z cukrzycą typu $1 \mathrm{i}$ ich krewnych. Diabetol Klin 2013; 2: 9-13.

8. Kahaly GJ, Hansen MP. Type 1 diabetes associated autoimmunity. Autoimmun Rev 2016; 15: 644-8.

9. Szcześniak G, Zdybel W, Kozak-Nurczyk P, Dziemidok P. Ocena rozpowszechnienia chorób uwarunkowanych autoimmunologicznie u pacjentów z cukrzycą i otyłością hospitalizowanych w Klinice Diabetologii Instytutu Medycyny Wsi w Lublinie. Fam Med Prim Care Rev 2016; 18: 354-7.

10. O'Meara NM, Blackman JD, Sturis J, Polonsky KS. Alterations in the kinetics of C-peptide and insulin secretion in hyperthyroidism. J Clin Endocrinol Metab 1993; 76: 79-84.

11. Mokuno T, Uchimura K, Hayashi R, et al. Glucose transporter 2 concentrations in hyper- and hypothyroid rat livers. J Endocrinol 1999; 160: 285-9.

12. Dimitriadis G, Baker B, Marsh H, et al. Effect of thyroid hormone excess on action, secretion and metabolism of insulin in humans. Am J Physiol 1985; 48: E593-E601.

13. Beer SF, Parr JH, Temple RC, Hales CN. The effect of thyroid disease on proinsulin and C-peptide levels. Clin Endocrinol 1989; 30: 379-83.

14. Levin RJ, Smyth DH. The effect of the thyroid gland on intestinal absorption of hexoses. J Physiol 1963; 169. 755-69.

15. Leong KS, Wallymahmed M, Wilding J, MacFarlane I. Clinical presentation of thyroid dysfunction and Addison's disease in young adults with type 1 diabetes. Postgrad Med J 1999; 75: 467-70.

16. Dimitriadis G, Mitrou P, Lambadiari V, et al. Insulin action in adipose tissue and muscle in hypothyroidism. J Clin Endocrinol Metab 2006; 91: 4930-7.
17. Cettour-Rose P, Theander-Carrillo C, Asensio C, et al. Hypothyroidism in rats decreases peripheral glucose utilisation, a defect partially corrected by central leptin infusion. Diabetologia 2005; 48: 624-33.

18. Maratou E, Hadjidakis DJ, Kollias A, et al. Studies of insulin resistance in patients with clinical and subclinical hypothyroidism. Eur J Endocrinol 2009; 160: 785-90.

19. Maskey R, Shakya DR, Baranwal JK, Lavaju P, Karki P, Poudel SK. Hypothyroidism in diabetes mellitus patients in Eastern Nepal. Indian J Endocrinol Metab 2015; 19: 411-5.

20. Chen HS, Wu TE, Jap TS, et al. Subclinical hypothyroidism is a risk factor for nephropathy and cardiovascular diseases in type 2 diabetic patients. Diab Med 2007; 24: 1336-44.

21. Den Hollander JG, Wulkan RW, Mantel MJ, Berghout A. Correlation between severity of thyroid dysfunction and renal function. Clin Endocrinol 2005; 62: 423-7.

22. Kim BY, Kim CH, Jung CH, Mok JO, Suh KI, Kang SK. Association between subclinical hypothyroidism and severe diabetic retinopathy in Korean patients with type 2 diabetes. Endocr J 2011; 58: 1065-70. 